\title{
Genetic potential of segregating populations of red beans conducted by the bulk method with selection
}

\author{
J.A.N. Menezes Júnior ${ }^{1}$, J.E.S. Carneiro ${ }^{2}$, V.M.P.S. Menezes ${ }^{3}$ and \\ P.C.S. Carneiro ${ }^{3}$ \\ ${ }^{1}$ Embrapa Meio-Norte, Sinop, MT, Brasil \\ ${ }^{2}$ Departamento de Fitotecnia, Universidade Federal de Viçosa, Viçosa, MG, Brasil \\ ${ }^{3}$ Departamento de Biologia Geral, Universidade Federal de Viçosa, Viçosa, \\ MG, Brasil \\ Corresponding author: J.A.N. Menezes Júnior \\ E-mail: jose-angelo.junior@embrapa.br
}

Genet. Mol. Res. 15 (2): gmr.15027329

Received July 28, 2015

Accepted September 25, 2015

Published June 10, 2016

DOI http://dx.doi.org/10.4238/gmr.15027329

\begin{abstract}
This study evaluated the performance and estimated the genetic potential of segregating populations of red bean. Twenty populations of the second cycle of recurrent selection for red bean breeding at Universidade Federal de Viçosa were advanced to the $F_{5}$ generation in bulk with selection for grain appearance. Populations plus five controls were evaluated for grain yield in three dry seasons (2004, 2005, and 2007) in a $5 \times 5$ lattice design with three replications, in four 4-m long rows. In the mean of the three crops, populations formed three distinct groups in which some populations had a clearly superior grain yield. Populations 288RVCI, 291RVCI, 295RVCI, 297RVCI, 300RVCI, and 303RVCI were the most promising. Over generations, segregating populations by the bulk method with selection for grain appearance may have reduced variability in grain yield. The 300RVCI
\end{abstract}


population deserves further attention as it combines variability, high mean, and a high probability of generating above-standard lines.

Key words: Phaseolus vulgaris; Red bean; Quantitative genetics; Common bean breeding; Grain appearance

\section{INTRODUCTION}

Replacing existing bean cultivars with new common advantageous cultivars has been a constant challenge in bean breeding programs. The identification of new cultivars that meet the expectations of farmers and consumers involves research activities requiring dedication and, above all, continuity (Ramalho and Abreu, 2006). Although main goal of improvement has been increased grain yield, other features have also received the attention of breeders, such as disease resistance; abiotic and biotic stresses; plant architecture; and grain quality (Miklas et al., 2006; Hegay et al., 2013; Terán et al., 2013; Jost et al., 2014).

Because there are many traits to be improved in common bean, and no ideal line has been bred, the most suitable alternative for the development of lines combining several desirable phenotypes is hybridization. Usually, several segregating populations are obtained during improvement of autogamous plants using hybridization programs. However, not all associate a high mean with sufficient variability for selection of the interest trait. Therefore, populations that are unpromising for breeding should be discarded as soon as possible to prevent wasted time in evaluating underperforming lines. In the case of common bean, several strategies have been used to select segregating populations, including the method of Jinks and Pooni (1976); estimates of $\mathrm{m}$ $+\mathrm{a}$ and d (means components); diallel crosses; and molecular markers (Pereira et al., 2007; Mendes et al., 2009; Rocha et al., 2013; Silva et al., 2013a). These methods are useful for choosing more promising parents and populations, increasing the efficiency of breeding programs.

The method of Jinks and Pooni (1976) to choose segregating populations has been typically applied to the common bean in $\mathrm{F}_{2}$ and $\mathrm{F}_{3}$ generations (Carneiro et al., 2002; Cunha et al., 2005; Melo et al., 2006). However, information about the later generations is scarce. Normally, after hybridization, segregating populations are advanced to homozygosity, using some method of segregating populations for later breeding of lines.

Since variability in grain appearance of common bean is wide, selection for this trait by the bulk method did not reduce grain yield variability (Santos et al., 2001; Silva, 2009), in this case, the method is called "bulk with selection." The objective of the bulk with selection method is to save time in the selection of traits with high heritability during the segregation of populations, without affecting variability in quantitative traits.

The current study evaluated the performance and predicted the genetic potential of 20 segregating populations of red beans, conducted by the bulk method with selection for grain appearance.

\section{MATERIAL AND METHODS}

Twenty bean populations were derived from intercrosses of 17 families $\left(\mathrm{F}_{3: 7}\right)$ of the first cycle of recurrent selection for red bean breeding of the Federal University of Viçosa and three lines of purple beans (BRS Timbó, BRSMG Tesouro and VR-2). In the crosses, each parent participated in two intercrosses to obtain 20 segregating populations (Table 1). 
Table 1. Genealogy of segregating populations of the second cycle of recurrent selection for red bean breeding.

\begin{tabular}{|c|c|}
\hline Population & Genealogy \\
\hline $284 \mathrm{RVCI}$ & Vermelhinho/AB136//Vermelhinho/AFR19521/// Vermelhinho//Vermelhinho/IAPAR31 \\
\hline $285 \mathrm{RVCI}$ & Vermelhinho//Vermelhinho/AN9022180/// Vermelhinho//Vermelhinho/Aporé \\
\hline $286 \mathrm{RVCI}$ & Vermelhinho//Vermelhinho/Pérola /// Vermelhinho/Pérola//Vermelhinho/AFR19521 \\
\hline $287 \mathrm{RVCI}$ & Vermelhinho/AN9022180//Vermelhinho/Vermelho2157///Vermelhinho/IAPAR31//Vermelhinho/AFR19535 \\
\hline $288 \mathrm{RVCI}$ & Vermelhinho/AB136//Vermelhinho/Vermelho2157 /// Vermelhinho//Vermelhinho/LR720982CP \\
\hline 289 RVCI & Vermelhinho//Vermelhinho/IAPAR31 /// Vermelhinho//Vermelhinho/IAPAR81 \\
\hline $290 \mathrm{RVCI}$ & Vermelhinho//Vermelhinho/Aporé/// Vermelhinho/Aporé//Vermelhinho/AFR19521 \\
\hline $291 \mathrm{RVCI}$ & Vermelhinho/Pérola//Vermelhinho/AFR19521 /// Vermelhinho/Pérola//Vermelhinho/AB136 \\
\hline $292 \mathrm{RVCI}$ & Vermelhinho/IAPAR31//Vermelhinho/AFR19535 /// Vermelhinho/IAPAR31//Vermelhinho/AB136 \\
\hline 293 RVCI & Vermelhinho//Vermelhinho/LR720982CP /// Vermelhinho/LR720982//Vermelhinho/AB136 \\
\hline 294 RVCI & Vermelhinho//Vermelhinho/IAPAR81 /// Vermelhinho/AFR19521//Vermelhinho/Vermelho2157 \\
\hline $295 \mathrm{RVCI}$ & Vermelhinho/Aporé//Vermelhinho/AFR19521 /// Vermelhinho/AB136//Vermelhinho/Vermelho2157 \\
\hline $296 \mathrm{RVCI}$ & Vermelhinho/Pérola//Vermelhinho/AB136/// VR-2 \\
\hline $297 \mathrm{RVCI}$ & Vermelhinho/IAPAR31//Vermelhinho/AB136 /// BRSMG Tesouro \\
\hline $298 \mathrm{RVCI}$ & Vermelhinho/LR720982//Vermelhinho/AB136 /// BRS Timbó \\
\hline 299 RVCI & Vermelhinho/AFR19521//Vermelhinho/Vermelho2157/// Vermelhinho/AB136//Vermelhinho/AFR19521 \\
\hline $300 \mathrm{RVCI}$ & Vermelhinho/AB136//Vermelhinho/Vermelho2157 /// Vermelhinho//Vermelhinho/AN9022180 \\
\hline $301 \mathrm{RVCI}$ & VR-2 /// Vermelhinho//Vermelhinho/Pérola \\
\hline $302 \mathrm{RVCI}$ & BRSMG Tesouro /// Vermelhinho/AN9022180//Vermelhinho/Vermelho2157 \\
\hline 303 RVCI & BRS Timbó /// Vermelhinho/AB136//Vermelhinho/Vermelho2157 \\
\hline
\end{tabular}

Populations were advanced by the method bulk with selection for grain appearance, up to the $\mathrm{F}_{5}$ generation. In each generation, selection was based on the standard appearance of commercial grain: typically red grain with gloss; no flattening; an elliptical shape; and weighing between 22 and $24 \mathrm{~g}$ (for 100 grains weighed). Grains outside this commercial standard were eliminated. The populations, along with five controls, were evaluated for grain yield in generations $\mathrm{F}_{2}, \mathrm{~F}_{3}$ and $\mathrm{F}_{5}$, in the dry seasons of 2004, 2005 and 2007. The experiment had a 5 x 5 lattice design with three replications, planted in four $4 \mathrm{~m}$ rows and 15 seeds were sown per meter of row. The $\mathrm{F}_{4}$ generation was grown in the rainy season of 2006, but excessive rains damaged the experimental accuracy, and these data were excluded from statistical analysis. Experiments were conducted on the experimental farm of the Department of Plant Science - UFV, in Coimbra, Minas Gerais (latitude $20^{\circ} 45^{\prime} \mathrm{S}$, longitude $42^{\circ} 51^{\prime} \mathrm{W}$, at $690 \mathrm{~m}$ above sea level).

Data for grain yield in $\mathrm{kg} / \mathrm{ha}$ were subjected to analysis of variance per generation, considering all effects as fixed, according to the statistical model:

$$
\mathrm{Y}_{\mathrm{ikl}}=\mathrm{m}+\mathrm{p}_{\mathrm{i}}+\mathrm{r}_{\mathrm{k}}+\mathrm{b}_{\mathrm{l}(\mathrm{k})}+\mathrm{e}_{\mathrm{ikl}}
$$

(Equation 1)

In the above model, $\mathrm{Y}_{\mathrm{ikl}}$ is the value observed in plots that received treatment $\mathrm{i}$ in block 1 in replication $\mathrm{k} ; \mathrm{m}$ is the overall mean; $\mathrm{p}_{\mathrm{i}}$ the effect of treatment $\mathrm{i}(\mathrm{i}=1,2,3, \ldots, 25) ; \mathrm{r}_{\mathrm{k}}$ the effect of replication $\mathrm{k}(\mathrm{k}=1,2$ and 3$) ; \mathrm{b}_{\mathrm{l}(\mathrm{k})}$ the effect of block 1 in replication $\mathrm{k}$; and $\mathrm{e}_{\mathrm{ikl}}$ the experimental error associated with observation $\mathrm{Y}_{\mathrm{ik}}$, assuming that the errors are independent, normally distributed with zero mean and variance $\sigma^{2}$. Combined analysis of variance was subsequently performed, using the adjusted means of the treatment and the method described by Ramalho et al. (2012). Grain yield means were grouped using the Scott and Knott (1974) test at $1 \%$ significance. Means of grain appearance were compared with means of control Ouro Vermelho, by the Dunnett test at $1 \%$ confidence. 
In the $\mathrm{F}_{5}$ generation, one central row per plot was earmarked to measure grain yield per plant, to apply the methodology of Jinks and Pooni (1976) and to estimate the probability (P) of each segregating population of originating lines that exceed the productivity of cultivar Ouro Vermelho by $30 \%$. All plants of one of the central rows of the plot were threshed separately. This probability corresponds to the area on the right or left of a given value $\mathrm{x}$ on the abscissa of the normal distribution. To determine this area, an estimate of the $\mathrm{Z}$ ordinate was used, by the expression:

$$
\mathrm{Z}=(\mathrm{x}-\mathrm{m}) / \mathrm{s}
$$

(Equation 2)

where: $\mathrm{x}$ is the mean of the standard line $(\bar{L})$ which is, in this case, the mean of cultivar Ouro Vermelho plus $30 \%$; $m$ is the mean of the lines in the Fo generation, which, in a model without dominance, corresponds to the mean of any segregating generation $\left(\bar{F}_{n_{i}}\right) ; \mathrm{s}$ is the phenotypic standard deviation between the lines

$$
\left(s=\sqrt{\hat{\sigma}_{F_{L}}^{2}}\right)
$$

The variance between the lines $\left(\hat{\sigma}_{G_{L}}^{2}\right)$ is twice as high as the additive genetic variance $\left(\hat{\sigma}_{A}^{2}\right)$ in the $\mathrm{F}_{2}$ generation. For a model without dominance, the phenotypic variance of the $\mathrm{F}_{2}$ generation $\left(\hat{\sigma}_{F_{F_{2}}}^{2}\right)$ contains $\hat{\sigma}_{A}^{2}+\hat{\sigma}_{E}^{2}$. Therefore,

$$
2 \hat{\sigma}_{A}^{2}=2 \hat{\sigma}_{F_{F_{2}}}^{2}-2 \hat{\sigma}_{E}^{2}
$$

Considering that the environmental variance of the $\mathrm{F}_{2}$ generation can be estimated by the variance of the lines (controls), we have

$$
s=\sqrt{\hat{\sigma}_{F_{L}}^{2}}=\sqrt{2 \hat{\sigma}_{A}^{2}+\hat{\sigma}_{E}^{2}}=\sqrt{2 \hat{\sigma}_{F_{F_{2}}}^{2}-\hat{\sigma}_{E}^{2}}
$$

Therefore, for a given population $\mathrm{i}$ in the $\mathrm{F}_{2}$ generation,

$$
Z_{i}=\left(\bar{L}-\bar{F}_{2_{i}}\right) / \sqrt{\left(2 \hat{\sigma}_{F_{F_{2 i}}}^{2}-\hat{\sigma}_{E}^{2}\right)}
$$

For populations evaluated in the $\mathrm{F}_{5}$ generation, the phenotypic variance is:

$$
\hat{\sigma}_{F_{F_{5}}}^{2}=1.88 \hat{\sigma}_{A}^{2}+\hat{\sigma}_{E}^{2}
$$

Therefore,

$$
\hat{\sigma}_{A}^{2}=\left\lfloor\left(\hat{\sigma}_{F_{F_{5}}}^{2}-\sigma_{E}^{2}\right) \div 1.88\right\rfloor
$$

Thus, the probability that a given population $\mathrm{i}\left(\mathrm{F}_{5}\right.$ generation) will generate above-standard lines was estimated by the expression: 


$$
Z_{i}=\left(\bar{L}-\bar{F}_{S_{i}}\right) / \sqrt{\left(1.064 \hat{\sigma}_{F_{F_{5}}}^{2}-0.064 \hat{\sigma}_{E}^{2}\right)}
$$

(Equation 9)

From each population in the $\mathrm{F}_{5}$ generation, 19 plants were selected. These plants resulted in $380 \mathrm{~F}_{5: 6}$ families, which together with 20 controls were evaluated in the 2007 winter season, in a $20 \times 20$ simple lattice design, in $2 \mathrm{~m}$ row plots. In the 2008 dry season, eight families $\left(\mathrm{F}_{5: 7}\right)$ per population were evaluated, along with nine controls in a $13 \times 13$ triple lattice design and plots of two $2 \mathrm{~m}$ rows. From the mean of the $\mathrm{F}_{5: 6}$ and $\mathrm{F}_{5: 7}$ generations, the number of families among the $50(50+), 30(30+)$ and 10 highest yielding families $(10+)$ was determined.

\section{RESULTS AND DISCUSSION}

A significant effect of the source of variation (Table 2) was observed for populations, indicating the possibility of selecting populations that, based on the mean, could be used to generate lines with high yield performance. The population $\mathrm{x}$ environment interaction was not significant, indicating a consistent behavior of populations in the three environments. It is worth remembering that the effect of environments is confounded with the effect of years and generations, since the evaluations were conducted in the dry season, but in different years and generations.

Table 2. Combined analysis of variance of grain yield $(\mathrm{kg} / \mathrm{ha})$ in assessment of 20 segregating populations of red beans $\left(F_{2}, F_{3}\right.$, and $F_{5}$ generations $)$ in the 2004, 2005, and 2007 dry seasons in Coimbra - MG.

\begin{tabular}{|c|c|c|c|}
\hline Source of variation & d.f. & Mean square & $\mathrm{P}$ \\
\hline Environments & 2 & 65746059.54 & 0.000 \\
\hline Treatments & 24 & 323357.80 & 0.000 \\
\hline Populations & 19 & 235942.73 & 0.000 \\
\hline Controls & 4 & 805410.57 & 0.000 \\
\hline Populations $v s$ controls & 1 & 56033.04 & 0.403 \\
\hline Treatments $\mathrm{x}$ environments & 48 & 136340.94 & 0.009 \\
\hline Populations $\mathrm{x}$ environments & 38 & 99716.04 & 0.180 \\
\hline Controls $\mathrm{x}$ environments & 8 & 320143.47 & 0.000 \\
\hline Populations $v s$ controls $\mathrm{x}$ environments & 2 & 97003.93 & 0.299 \\
\hline Mean error & 120 & 79653.50 & - \\
\hline Coefficient of variation $(\%)=8.90$ & - & - & - \\
\hline Overall mean $=3170.40$ & - & - & - \\
\hline
\end{tabular}

DF - Degrees of freedom; P - probability.

By the Scott and Knott (1974) test, in the mean of the three environments populations formed three distinct groups (Table 3), showing grain yield superiority for some. This indicated the possibility of selecting promising populations to extract lines. However, even populations with a lower performance may generate highly productive lines, since in this case, only the mean was considered, and there is no information on genetic variability within populations.

For grain appearance, the grades of the populations did not differ from the grade of the control Ouro Vermelho by Dunnett's test at 1\% confidence level (Table 3), indicating the potential for extracting lines with red grains.

To predict the potential of segregating populations to generate high-yielding lines, in the 2007 dry season, the grain yield per plant was assessed in each population ( $\mathrm{F}_{5}$ generation). The methodology of Jinks and Pooni (1976) was used, which allows an estimation of the probability that the segregating population will generate lines with a standard above a certain performance. For this purpose, the mean of cultivar Ouro Vermelho was used as a reference 
(Table 4) plus 30\% (29.96 g). The environmental variance (175.31) was obtained based on the mean phenotypic variance of the five controls. This methodology has been widely used for common bean (Carneiro et al., 2002; Cunha et al., 2005).

\begin{tabular}{|c|c|c|c|c|c|}
\hline Population/control & $\mathrm{GA}^{*}$ & $2004\left(\mathrm{~F}_{2}\right)^{\dagger}$ & $2005\left(\mathrm{~F}_{3}\right)^{\dagger}$ & $2007\left(\mathrm{~F}_{5}\right)^{\dagger}$ & Mean $^{\dagger}$ \\
\hline Vermelho 2157 & 3.7 & $2226^{\mathrm{a}}$ & $3558^{\mathrm{a}}$ & $4424^{a}$ & $3403^{\mathrm{a}}$ \\
\hline Ouro Negro & 5.0 & $2488^{\mathrm{a}}$ & $3648^{\mathrm{a}}$ & $4039^{\mathrm{a}}$ & $3392^{\mathrm{a}}$ \\
\hline Ouro Vermelho & 1.5 & $2392^{\mathrm{a}}$ & $3304^{\mathrm{a}}$ & $4475^{\mathrm{a}}$ & $3390^{\mathrm{a}}$ \\
\hline $285 \mathrm{RVCI}$ & 2.0 & $2314^{\mathrm{a}}$ & $3233^{\mathrm{a}}$ & $4568^{\mathrm{a}}$ & $3371^{a}$ \\
\hline $295 \mathrm{RVCI}$ & 1.5 & $2207^{\mathrm{a}}$ & $3455^{\mathrm{a}}$ & $4379^{\mathrm{a}}$ & $3347^{\mathrm{a}}$ \\
\hline $297 \mathrm{RVCI}$ & 2.4 & $2331^{\mathrm{a}}$ & $3538^{\mathrm{a}}$ & $4127^{\mathrm{a}}$ & $3332^{\mathrm{a}}$ \\
\hline $290 \mathrm{RVCI}$ & 2.3 & $2134^{\mathrm{b}}$ & $3530^{\mathrm{a}}$ & $4309^{\mathrm{a}}$ & $3324^{\mathrm{a}}$ \\
\hline $298 \mathrm{RVCI}$ & 2.3 & $2272^{\mathrm{a}}$ & $3279^{\mathrm{a}}$ & $4308^{a}$ & $3286^{\mathrm{a}}$ \\
\hline $302 \mathrm{RVCI}$ & 3.0 & $2369^{\mathrm{a}}$ & $3483^{\mathrm{a}}$ & $3957^{\mathrm{a}}$ & $3269^{\mathrm{a}}$ \\
\hline $288 \mathrm{RVCI}$ & 1.8 & $2086^{\mathrm{b}}$ & $3453^{\mathrm{a}}$ & $4231^{\mathrm{a}}$ & $3256^{\mathrm{a}}$ \\
\hline $293 \mathrm{RVCI}$ & 1.6 & $2063^{\mathrm{b}}$ & $3329^{\mathrm{a}}$ & $4251^{a}$ & $3214^{a}$ \\
\hline 294 RVCI & 1.7 & $2014^{\mathrm{b}}$ & $3695^{\mathrm{a}}$ & $3928^{a}$ & $3212^{\mathrm{a}}$ \\
\hline $300 \mathrm{RVCI}$ & 1.8 & $2189^{\mathrm{a}}$ & $3379^{\mathrm{a}}$ & $4024^{\mathrm{a}}$ & $3197^{\mathrm{a}}$ \\
\hline $299 \mathrm{RVCI}$ & 2.3 & $2216^{\mathrm{a}}$ & $3395^{\mathrm{a}}$ & $3942^{\mathrm{a}}$ & $3184^{\mathrm{a}}$ \\
\hline $301 \mathrm{RVCI}$ & 2.9 & $2124^{\mathrm{b}}$ & $3469^{\mathrm{a}}$ & $3936^{\mathrm{a}}$ & $3176^{\mathrm{a}}$ \\
\hline $284 \mathrm{RVCI}$ & 1.1 & $1974^{\mathrm{b}}$ & $3326^{\mathrm{a}}$ & $4182^{\mathrm{a}}$ & $3161^{a}$ \\
\hline Vermelhinho & 1.5 & $1908^{\mathrm{b}}$ & $3250^{\mathrm{a}}$ & $4178^{\mathrm{a}}$ & $3112^{b}$ \\
\hline $296 \mathrm{RVCI}$ & 2.6 & $2200^{\mathrm{a}}$ & $3223^{\mathrm{a}}$ & $3874^{\mathrm{a}}$ & $3099^{b}$ \\
\hline $303 \mathrm{RVCI}$ & 2.2 & $2355^{\mathrm{a}}$ & $3258^{\mathrm{a}}$ & $3679^{\mathrm{a}}$ & $3097^{\mathrm{b}}$ \\
\hline $291 \mathrm{RVCI}$ & 1.9 & $1983^{b}$ & $3032^{\mathrm{a}}$ & $4077^{\mathrm{a}}$ & $3031^{b}$ \\
\hline $287 \mathrm{RVCI}$ & 1.6 & $2081^{\mathrm{b}}$ & $3289^{\mathrm{a}}$ & $3660^{\mathrm{a}}$ & $3010^{\mathrm{b}}$ \\
\hline $289 \mathrm{RVCI}$ & 1.9 & $1998^{\mathrm{b}}$ & $3192^{\mathrm{a}}$ & $3833^{\mathrm{a}}$ & $3008^{b}$ \\
\hline $286 \mathrm{RVCI}$ & 1.8 & $1996^{\mathrm{b}}$ & $3221^{\mathrm{a}}$ & $3707^{\mathrm{a}}$ & $2975^{\mathrm{b}}$ \\
\hline AFR-140 & 3.6 & $2320^{\mathrm{a}}$ & $2671^{a}$ & $3151^{\mathrm{a}}$ & $2714^{\circ}$ \\
\hline $292 \mathrm{RVCI}$ & 1.4 & $1893^{\mathrm{b}}$ & $3001^{\mathrm{a}}$ & $3204^{\mathrm{a}}$ & $2699^{\circ}$ \\
\hline Coefficient of variation (\%) & 11.1 & 5.8 & 10.3 & 8.9 & 8.9 \\
\hline
\end{tabular}

${ }^{a}$ Means followed by the same letter in a column do not differ by the Scott and Knott test at $1 \%$ probability. ${ }^{*}$ By the Dunnett test at $1 \%$ probability, population mean grain appearance did not differ from the mean of the standard control Ouro Vermelho.

For this methodology, the mean of any segregating generation $\left(\bar{F}_{n_{i}}\right)$ is considered to correspond to the mean of the lines in the Fo generation (Jinks and Pooni, 1976). However, additive gene action has to be predominant. For common bean, studies have reported a predominance of additive effects for grain yield (Nienhuis and Singh, 1986; Kurek et al., 2001). However, the predominance of dominance effects associated with grain yield has also been described in studies analyzing $F_{1}$ or $F_{2}$ generations (Rodrigues et al., 1998; GonçalvesVidigal et al., 2008; Silva et al., 2013b). This suggests that the methodology of Jinks and Pooni (1976) is more appropriate for later generations, in which dominance effects are minimized. In the current study, the methodology was applied in the $\mathrm{F}_{5}$ generation, and dominance effects were considered absent.

The probabilities $(\mathrm{P})$ that the populations would originate lines that exceeded the mean of Ouro Vermelho line by $30 \%$ are presented in Table 4 . Among the 20, genetic variance within populations was detected in only five (populations 287RVCI, 291RVCI, 292RVCI, 296RVCI, and 300RVCI), and 300RVCI had the highest probability (49.60\%) of generating above-standard lines. In the mean of the three environments (Table 3), four of five populations 
were not grouped with the highest yielding, by the Scott and Knott (1974) test. Only population 300RVCI was classified among the most productive, indicating that this population also has a high mean, aside from variability, which is favorable for selection.

Table 4. Total number of assessed plants (NAP), grain yield per plant (g/plant), mean phenotypic variance $\left(\hat{\sigma}_{\bar{F}}^{2}\right)$, genetic variances $\left(\hat{\sigma}_{\bar{G}}^{2}\right), \mathrm{Z}$ values, and their respective probabilities $(\mathrm{P})$ for each $\mathrm{F}_{5}$ population of red beans evaluated in the 2007 dry season in Coimbra - MG.

\begin{tabular}{|c|c|c|c|c|c|c|}
\hline Name & NAP & Yield (g/plant) & $\hat{\sigma}_{\bar{F} i}^{2}$ & $\hat{\sigma}_{\bar{G} i}^{2}$ & $\mathrm{Z}_{\mathrm{i}}$ & $\mathrm{P}^{\mathrm{a}}$ \\
\hline 284 RVCI & 123 & 20.35 & 128.72 & $-\mathrm{b}$ & 0.86 & 19.49 \\
\hline 285 RVCI & 114 & 19.74 & 126.44 & - & 0.92 & 17.88 \\
\hline $286 \mathrm{RVCI}$ & 133 & 20.00 & 144.00 & - & 0.84 & 20.05 \\
\hline 287 RVCI & 114 & 24.42 & 204.11 & 28.80 & 0.39 & 34.83 \\
\hline $288 \mathrm{RVCI}$ & 120 & 18.98 & 116.82 & - & 1.03 & 15.15 \\
\hline 289 RVCI & 145 & 18.39 & 109.26 & - & 1.13 & 12.92 \\
\hline $290 \mathrm{RVCI}$ & 148 & 18.58 & 136.01 & - & 0.99 & 16.11 \\
\hline $291 \mathrm{RVCI}$ & 120 & 22.84 & 223.64 & 48.33 & 0.47 & 31.92 \\
\hline 292 RVCI & 96 & 25.28 & 256.06 & 80.75 & 0.29 & 38.59 \\
\hline 293 RVCI & 132 & 21.59 & 167.32 & - & 0.65 & 25.78 \\
\hline 294 RVCI & 105 & 22.22 & 138.64 & - & 0.66 & 25.46 \\
\hline 295 RVCI & 133 & 21.22 & 137.18 & - & 0.75 & 22.66 \\
\hline 296 RVCI & 115 & 21.34 & 203.06 & 27.74 & 0.60 & 27.42 \\
\hline 297 RVCI & 138 & 20.07 & 174.55 & - & 0.75 & 22.66 \\
\hline $298 \mathrm{RVCI}$ & 127 & 20.19 & 162.86 & - & 0.77 & 22.06 \\
\hline 299 RVCI & 123 & 19.94 & 135.19 & - & 0.87 & 19.21 \\
\hline $300 \mathrm{RVCI}$ & 94 & 29.75 & 365.28 & 189.96 & 0.01 & 49.60 \\
\hline $301 \mathrm{RVCI}$ & 154 & 18.73 & 155.37 & - & 0.90 & 18.41 \\
\hline 302 RVCI & 134 & 19.69 & 164.73 & - & 0.80 & 21.18 \\
\hline 303 RVCI & 119 & 18.44 & 150.62 & - & 0.94 & 17.36 \\
\hline Vermelhinho & 136 & 19.92 & 130.33 & - & $-\mathrm{c}$ & $--^{c}$ \\
\hline Vermelho 2157 & 117 & 24.14 & 196.54 & - & - & - \\
\hline Ouro Vermelho & 135 & 23.04 & 224.79 & - & - & - \\
\hline AFR-140 & 146 & 14.45 & 112.73 & - & - & - \\
\hline Ouro Negro & 123 & 20.98 & 212.19 & - & - & - \\
\hline
\end{tabular}

${ }^{a}$ The probability $(\mathrm{P})$ cannot be inferred for populations with zero genetic variance. Values in $\%$. ${ }^{\mathrm{b}}$ Genetic variance zero. ${ }^{\mathrm{C}} \mathrm{Zi}$ and $\mathrm{P}$ were not estimated for the controls.

For the other populations, the P calculated could not be interpreted, because it only takes into account the mean, since the phenotypic variance, used to calculate the estimate, is purely environmental. Null values for genetic variance indicate that the estimate of environmental variance, based on controls, may not represent the true environmental variation within populations. One possible cause may be the occurrence of genetic variations within controls, due to mutations, natural breeding, mechanical seed mixing, or other factors. These may lead to an overestimation of the environmental variance, hampering the estimation of genetic variance within populations.

In this study, evaluations were performed in three crop cycles. It is therefore possible that some variation occurred in the controls from one crop cycle to the next. In addition, some controls may contain genetic variation within, depending on the way they were bred. For example, the control Ouro Vermelho had the highest phenotypic variance (Table 4). This control was derived from an $\mathrm{F}_{3}$ plant advanced in bulk within the family (Carneiro et al., 2006), and can be considered a multiline. This fact emphasizes the importance of using inbred lines as controls to estimate the environmental effect, when applying the methodology of Jinks and Pooni (1976). 
Another possible cause for zero variance is the use of individual plants as a basic evaluation unit. Not only is the evaluation of individual plants labor-intensive, but it is normally associated with errors, and may therefore impair an accurate estimation of the variance. Zero variance has been commonly reported in assessments of individual common bean plants by the methodology of Jinks and Pooni (1976) (Carneiro et al., 2002; Cunha et al., 2005; Melo et al., 2006).

One of the causes of problems when evaluating individual plants is variation in the final stand. In this study, all plants of one of the central rows of the plot were threshed separately. Table 4 shows a large variation in final stand, since 94 plants of population 300RVCI versus 154 of 301 RVCI were evaluated. It was also observed that the variation in the number of assessed plants affected the mean yield per plant (Table 4). The correlation between the final stand (total number of assessed plants, NAP) and the mean yield per plant was negative and significant (-0.73), indicating that the lower the final stand, the greater the yield per plant. Therefore, differences in the final stand, apart from affecting the estimation of variance, may cause overestimation of the plant mean in populations with low density, and hamper application of the methodology of Jinks and Pooni (1976), which takes into account the mean and variance of the population.

Since the populations were conducted by the bulk method with selection for grain appearance, a reduction in yield variability may have occurred. This may also have contributed to a genetic variance of zero in most populations. Santos et al. (2001) reported that selection for grain appearance did not affect yield variability, but selection was performed in only one generation. In the current study, selection was applied in three generations $\left(\mathrm{F}_{2}, \mathrm{~F}_{3}\right.$, and $\left.\mathrm{F}_{4}\right)$. Using the bulk selection method over several generations, Silva (2009) found that selection for grain type did not affect grain yield variability.

Since the methodology of Jinks and Pooni (1976) was only applied in the 2007 dry season, the genotype $\mathrm{x}$ environment (GE) interaction may also have contributed to the result of zero genetic variance within populations, indicating that assessments should be conducted in more environments. Rocha et al. (2013) found that the GE interaction influenced the prediction of the potential of segregating populations.

The families $\mathrm{F}_{5: 6}$ and $\mathrm{F}_{5: 7}$, selected from 20 populations, were evaluated for grain yield. Considering the mean of both generations, the population with the largest number of families among the 10 most productive was $291 \mathrm{RVCI}$ (Table 5). The probability of deriving abovestandard lines from this population was $31.92 \%$, according to the methodology of Jinks and Pooni (1976), however, in the mean of the three assessments, this population was not grouped among the highest yielding by the Scott and Knott (1974) test. On the other hand, population 300RVCI, with the highest probability of generating above-standard lines $(49.60 \%)$, was ranked among the highest yielding by the Scott and Knott (1974) test but was represented by only one family among the 30 highest yielding.

Of the five populations with genetic variance within, by the evaluation of individual plants, two (292RVCI and 296RVCI) were not represented among the 50 most productive (Table 5). This indicates that these populations have genetic variability, albeit with low mean. In the populations 288RVCI, 295RVCI and 297RVCI on the other hand, no genetic variance was detected in the assessment of separate plants, but they were represented by two families among the 10 highest yielding (Table 5). In general, the studied populations have potential for breeding lines, of which $80 \%$ were represented with at least one family among the 50 most productive (Table 5). 
Table 5. Mean, lower limit (LI) and upper limit (LS), grain yield ( $\mathrm{kg} / \mathrm{ha})$, number of lines (NL) per population among the fifty $(50+)$, thirty $(30+)$, and ten $(10+)$ most productive, obtained by the evaluation of $\mathrm{F}_{5: 6}$ and $\mathrm{F}_{5: 7}$ red bean families in the winter of 2007 and dry season of 2008, respectively, in Coimbra - MG.

\begin{tabular}{|c|c|c|c|c|c|c|}
\hline Population & Mean & LI & LS & $\mathrm{NL}(50+)$ & $\mathrm{NL}(30+)$ & NL $(10+)$ \\
\hline 284 RVCI & 3501 & 3351 & 3734 & 1 & 0 & 0 \\
\hline 285 RVCI & 3531 & 3118 & 3964 & 3 & 3 & 0 \\
\hline 286 RVCI & 3506 & 3082 & 3848 & 3 & 1 & 0 \\
\hline 287 RVCI & 3409 & 3069 & 3802 & 1 & 1 & 0 \\
\hline $288 \mathrm{RVCI}$ & 3809 & 3664 & 4155 & 7 & 3 & 2 \\
\hline 289 RVCI & 3564 & 3265 & 3852 & 3 & 1 & 0 \\
\hline 290 RVCI & 3451 & 3104 & 3786 & 2 & 0 & 0 \\
\hline 291 RVCI & 3800 & 3445 & 4206 & 5 & 5 & 3 \\
\hline 292 RVCI & 3450 & 3323 & 3673 & 0 & 0 & 0 \\
\hline 293 RVCI & 3349 & 2940 & 3761 & 2 & 0 & 0 \\
\hline 294 RVCI & 3460 & 2855 & 3851 & 4 & 3 & 0 \\
\hline $295 \mathrm{RVCI}$ & 3758 & 3580 & 3980 & 4 & 3 & 2 \\
\hline 296 RVCI & 3227 & 2922 & 3489 & 0 & 0 & 0 \\
\hline 297 RVCI & 3524 & 3006 & 4127 & 2 & 2 & 2 \\
\hline 298 RVCI & 3743 & 3568 & 3909 & 6 & 2 & 0 \\
\hline 299 RVCI & 3296 & 2978 & 3584 & 0 & 0 & 0 \\
\hline $300 \mathrm{RVCI}$ & 3524 & 3102 & 3916 & 1 & 1 & 0 \\
\hline $301 \mathrm{RVCI}$ & 3160 & 2630 & 3484 & 0 & 0 & 0 \\
\hline 302 RVCI & 3565 & 3269 & 3952 & 2 & 2 & 0 \\
\hline 303 RVCI & 3734 & 3338 & 4122 & 4 & 3 & 1 \\
\hline
\end{tabular}

\section{CONCLUSIONS}

The populations 288RVCI, 291RVCI, 295RVCI, 297RVCI, 300RVCI, and 303RVCI are the most promising for generate lines with red grains and high productivity.

The population 300RVCI associated genetic variability, high mean, and high probability of generating lines superior to the standard cultivar.

\section{ACKNOWLEDGMENTS}

The authors wish to thank the Foundation for Research Support of the State of Minas Gerais - FAPEMIG; Coordination of Improvement of Higher Education Personnel - CAPES; and the National Council for Scientific and Technological Development - CNPq, for funding projects developed by the Common Bean Breeding Program of the Federal University of Viçosa, and for scholarships.

\section{REFERENCES}

Carneiro JES, Ramalho MAP, Abreu AFB and Gonçalves FMA (2002). Breeding potential of single, double and multiple crosses in common bean. Crop Breed. Appl. Biotechnol. 2: 515-524. http://dx.doi.org/10.12702/1984-7033. v02n04a 04

Carneiro JES, Silva LC, Paula Junior TJ, Araujo GAA, et al. (2006). 'Ouro Vermelho': new red bean cultivar for Minas Gerais. The Bean Improvement Cooperative annual report No. 49, East Langing, MI, 281-282.

Cunha WG, Ramalho MAP and Abreu AFB (2005). Selection aiming at upright growth habit common bean with carioca type grains. Crop Breed. Appl. Biotechnol. 5: 379-386. http://dx.doi.org/10.12702/1984-7033.v05n04a02

Gonçalves-Vidigal MC, Silvério L, Elias HT, Vidigal Filho PS, et al. (2008). Combining ability and heterosis in common bean cultivars. Pesquisa Agropecu. Bras. 43: 1143-1150. http://dx.doi.org/10.1590/S0100-204X2008000900007

Hegay S, Ortiz R, Garkava-Gustavsson L, Hovmalm HP, et al. (2013). Marker-aided breeding for resistance to bean common mosaic virus in Kyrgyz bean cultivars. Euphytica 193: 67-78. http://dx.doi.org/10.1007/s10681-013-0928-9 
Jinks JL and Pooni HS (1976). Predicting the properties of recombinant inbred lines derived by single seed descent. Heredity 36: 253-266. http://dx.doi.org/10.1038/hdy.1976.30

Jost E, Ribeiro ND, Rosa DP, Possobom MTDF, et al. (2014). Methods of selecting common bean lines having high yield, early cycle and erect growth. Rev. Cienc. Agron. 45: 101-110. http://dx.doi.org/10.1590/S1806-66902014000100013

Kurek AJ, Carvalho FIF, Assmann IC and Cruz PJ (2001). Combining ability as an efficiency criterion in the parental bean selection. Pesquisa Agropecu. Bras. 36: 645-651. http://dx.doi.org/10.1590/S0100-204X2001000400007

Melo CLP, Carneiro JES, Carneiro PCS, Silva LC, et al. (2006). Predicting the genetic potential in segregating populations of common bean (Phaseolus vulgaris L.). The Bean Improvement Cooperative annual report No. 49, East Langing, MI, 139-140.

Mendes FF, Ramalho MAP and Abreu AFB (2009). Selection index for choosing segregating populations in common bean. Pesquisa Agropecu. Bras. 44: 1312-1318. http://dx.doi.org/10.1590/S0100-204X2009001000015

Miklas PN, Kelly JD, Beebe SE and Blair MW (2006). Common bean breeding for resistance against biotic and abiotic stresses: from classical to MAS breeding. Euphytica 147: 105-131. http://dx.doi.org/10.1007/s10681-006-4600-5

Nienhuis J and Singh SP (1986). Combining ability analyses and relationships among yield, yield components and architectural traits in dry bean. Crop Sci. 26: 21-27. http://dx.doi.org/10.2135/cropsci1986.0011183X002600010005x

Pereira HS, Santos JB, Abreu AFB and Couto KR (2007). Choice of common bean segregant populations using phenotypic information and QTL microsatellite markers. Pesquisa Agropecu. Bras. 42: 707-713. http://dx.doi.org/10.1590/ $\underline{\text { S0100-204X2007000500014 }}$

Ramalho MAP and Abreu AFB (2006). Cultivares. In: Feijão (Vieira C, Paula Júnior TJ and Borém A, eds.). 2nd edn. Universidade Federal de Viçosa, Viçosa, 415-436.

Ramalho MAP, Ferreira DF and Oliveira AC (2012). Experimentação em genética e melhoramento de plantas. 3rd edn. Universidade Federal de Lavras, Lavras.

Rocha GS, Carneiro JES, Rezende Júnior LS, Silva VMP, et al. (2013). Effect of environments on the estimated genetic potential of segregating common bean populations. Crop Breed. Appl. Biotechnol. 13: 241-248. http://dx.doi. org $/ 10.1590 /$ S1984-70332013000400004

Rodrigues R, Leal NR and Pereira MG (1998). Diallel analysis of six agronomic traits in Phaseolus vulgaris L. Bragantia 57: 241-250.

Santos VS, Ramalho MAP, Carneiro JES and Abreu AFB (2001). Consequences of early selection for grain type in common bean breeding. Crop Breed. Appl. Biotechnol. 1: 347-354. http://dx.doi.org/10.13082/1984-7033.v01n04a03

Scott AJ and Knott M (1974). A cluster-analysis method for grouping means in analysis of variance. Biometrics 30: 507 512. http://dx.doi.org/10.2307/2529204

Silva LC (2009). Estratégias de condução de populações segregantes no melhoramento genético do feijoeiro. Doctoral thesis, Universidade Federal de Viçosa, Viçosa.

Silva VMP, Menezes Júnior JAN, Carneiro PCS, Carneiro JES, et al. (2013a). Genetic improvement of plant architecture in the common bean. Genet. Mol. Res. 12: 3093-3102. PubMed http://dx.doi.org/10.4238/2013.January.30.8

Silva VMP, Carneiro PCS, Menezes Júnior JAN, Carneiro VQ, et al. (2013b). Genetic potential of common bean parents for plant architecture improvement. Sci. Agric. 70: 167-175. http://dx.doi.org/10.1590/S0103-90162013000300005

Terán H, Jara C, Mahuku G, Beebe S, et al. (2013). Simultaneous selection for resistance to five bacterial, fungal, and viral diseases in three Andean x Middle American inter-gene pool common bean populations. Euphytica 189: 283-292. http://dx.doi.org/10.1007/s10681-012-0803-0 